\title{
A Comparative Study of Ideational Grammatical Metaphor in Business and Political Texts
}

\author{
Yaser Hadidi \\ Dept. of English, Tabriz State University, Tabriz, Iran \\ E-mail: hadidiy@yahoo.com
}

Ali Raghami (Corresponding author)

Department of ELT, Islamic Azad University, Tabriz Branch, Tabriz, Iran

E-mail: aliragami@yahoo.com

Received: March 3, 2012 Accepted: March 10, 2012 Published: June 1, 2012

doi:10.5296/ijl.v4i2.1853ＵRL: http://dx.doi.org/10.5296/ijl.v4i2.1853

\begin{abstract}
Grammatical Metaphor constitutes a key building block of Systemic Linguistics and has a great contribution to the theory of metaphor. This paper addresses itself to the first type of grammatical metaphor, i.e. the ideational one. In ideational metaphors, lexico-grammatical features constitute alternative ways of constructing a picture of reality. The main objective of the current work is to analyze a corpus comprising three business and three political texts. . The texts were analyzed to see how many instances of ideational metaphor are used and what the respective frequencies are, as well as the role and function of ideational metaphor in business and political texts. The analysis brought out the finding that ideational metaphor has indeed pervaded political and business texts. Nominalization has been used in both of the genres, turning the process (verb) to a concept (noun). As a consequence, the tone of the writing sounds more abstract and more formal. In business, the instances of grammatical metaphor aren't coloured and fuelled by relations of power and ideology. In politics, however, they evidence indicators of uneven power by discursive agents of dominance. Some implications accrue to these findings, as well as some qualitative conclusions, in reference to discourse and translation studies, or teachers involved in writing instruction, to name only a few.
\end{abstract}

Keywords: Grammatical metaphor, Idetional metaphor, Nominalization, Business and politics tests 


\section{Introduction}

Grammatical metaphor as defined by Halliday (1985) for the first time (and refined and burnished in his successive works of 1994 and 2004; along with the valuable and constructive works of his colleagues) is a substitution of one grammatical class, or one grammatical structure by another. The term grammatical metaphor, as conceptualized by Halliday, fulfills certain important needs in discourse and text, including opening up a new dimension of a semantic space.

The study of the uses of grammatical metaphor is particularly useful in revealing how processes are changed into objects. Grammatical metaphor in this case changes not only the grammar of the texts but also the reader's reaction to texts. In this spirit, political and business texts have always been an interesting area for analysis and discussion, especially in terms of grammatical metaphor.

Discourse analysis of political and business texts has had a long history, but most of the analysis has concerned itself with lexical features and there are few studies that analyze texts and compare them regarding grammatical metaphor.

Ideational grammatical metaphor is the first type of grammatical metaphor. In ideational grammatical metaphor, lexico-grammatical features are re-arranged to put forth a certain view of reality. They constitute an alternative way of constructing a picture of reality. Nominalization is the most common form of ideational grammatical metaphor, especially in science, technology, political and business discourse. Nominalization turns actions or processes into concepts, while also reducing the number of clauses and compressing more information into each nominal group. As Halliday has argued in his IFGs (Introduction to Functional Grammar; in all three editions of 1985, 1994 and 2004), each nominalized or metaphorical wording in the metaphorical domain has its congruent wording in the congruent domain. The metaphorical domain explains the situation in more interesting and more formal ways in comparison with the congruent one.

\section{Review of Literature}

To pick up on Halliday and Matthiessen's (1999) fundamental outlook, grammatical metaphor is a means of having things both ways. A word that is transcribed loses its original status because of the nature of the semantic features with which it comes to be combined (e.g., like ...is a quality: so when we say mousy, like a mouse this is only a quality). An element that is metaphorized doesn't lose its original status. Its construction isn't triggered by its being associated with any new semantic feature. If it has a new semantic feature, this is as a result of the metaphorizing process. So failure is a both process and thing: it is a process formed as a thing; its initial status remains as a process, but because it has been nominalized, and the prototypical meaning of a noun is a thing, it also acquires a semantic status as something that participates in processes.

Halliday and Matthiessen (1999) explore the nature of GM in more depth by locating it in a broader theoretical environment of the meaning base in languages. According to Halliday and Matthiessen (1999), the emergence of GM is related to the natural development of the 
content plane in a language. Therefore, Halliday and Matthiessen (1999, p. 7) define GM as 'the phenomenon whereby a set of agnate forms is present in the language having different mappings between the semantic and the grammatical categories'.

Systemicists share a line of reasoning - e.g. Halliday and Matthiessen (1999), Romero and Soria (n.d.), Halliday and Matthiessen (2004), among others - that the traditional approach to metaphor is to look at it from below and ask what a certain expression means. For example, the lexical metaphor flood means either, literally, an inundation of water or, metaphorically, an intense emotion as in she felt a flood of relief. But we could look from above and ask how intense emotion is expressed. Then we could say it is expressed either, literary, as she felt very relieved or, metaphorically, as she felt a flood of relief.

Once we look from above in this way, we can see that the phenomenon under discussion is the same as metaphor in its traditional sense except that what is varied is not the lexis, but the grammar. Thus:

$$
\text { Clap }
$$

(a)

Lexical metaphor

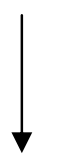

Applaud loudly= applaud thunderously
Loud noise

(b)

grammatical metaphor

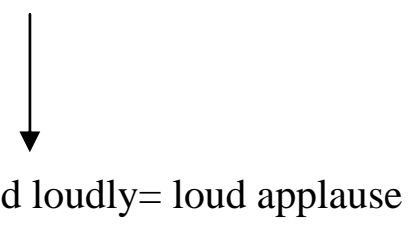

Figure 2.1. Lexical and grammatical metaphor

Thompson (2004) notes, in this connection, that the meaning of the message and the state of affairs referred to by the message are implied in the discussion of transitivity. And in fact transitivity analysis provides one rule of thumb for the recognition of grammatical metaphor. If transitivity analysis does not seem to reflect adequately the state of affairs being referred to, it is very likely that the meaning is being expressed metaphorically (p. 134). The ideational metafunction, which is what we are concerned with here, is closely tied to the transitivity system, which enables us to construe the world of our experience into a limited set of process types (material, mental, relational, behavioral, verbal and Existential). Processes are realized as a configuration of transitivity functions which represent the process, the participant in the situation, the attributes assigned to participants, and the circumstances associated with the process. These are typical patterns of lexico-grammatical realization (what Halliday calls congruent forms). The following table represents the process types in English (Martin et al, 1997). 
Table 2.1. Process Types in English

\begin{tabular}{|l|l|l|}
\hline Process type & subcategory & $\begin{array}{l}\text { Example clause (processes in } \\
\text { bold) }\end{array}$ \\
\hline Material & $\begin{array}{l}\text { Event } \\
\text { Action }\end{array}$ & $\begin{array}{l}\text { The sugar dissolved } \\
\text { She stirred the coffee }\end{array}$ \\
Mental & $\begin{array}{l}\text { Perception } \\
\text { Recognition } \\
\text { Affection }\end{array}$ & $\begin{array}{l}\text { She saw the car } \\
\text { She forget his name } \\
\text { She liked his music }\end{array}$ \\
Relational & $\begin{array}{l}\text { Attributive } \\
\text { Identifying }\end{array}$ & $\begin{array}{l}\text { Maggie was strong } \\
\text { Maggie was our leader }\end{array}$ \\
Eehavioral & & She laughed \\
Verbal & & $\begin{array}{l}\text { There was once a beautiful } \\
\text { princess }\end{array}$ \\
\hline
\end{tabular}

As Vandenbergan et al (2003) point out, throughout the history of language, demetaphorization occurs: grammatical metaphors gradually lose their metaphorical nature, and in this way become domesticated.

One of the key motivations in the study of GM would perhaps be the strata realignment of semantic and lexicogrammatical levels of the content plane in a language (Halliday and Matthiessen, 1999; Thompson, 2004; Yanning, 2008). Both Grammatical Metaphor and Lexical Metaphor involve a realignment between a pair of strata (the strata of semantics and grammar). This occurs by virtue of the stratified nature of linguistic systems where meaning is drawn up as abstract lexicogrammatical forms which leads to the possibility of different realizations (Marie \& Vanderbergen, 2003). Ravelli (2003) adds, in the discussion of the strata realignment involved in GM, that 'metaphorical processes depend on a kind of play between the two strata, a sense of two things happening at once, or a tension between the form and its meaning.' (p. 42).

Derevianka (2003) also discusses the stratified nature of language as a semiotic system which gives rise to the potential for metaphorical processes (Ravelli, 2003). Halliday (1978) noticed 
the different levels of language in his early studies of antilanguage in an article 'language in urban society'. In this early work, he attempts to explore the different social varieties of language in different contexts (Taverniers, 2003). The use of high varieties of language in formal contexts and low varieties in informal contexts is called 'the congruent pattern'.

\section{Methodology}

\subsection{Research Questions and Hypothesis}

Based on the main purpose of the research and the scope of the study, we would try to find a logical answer to the following research questions.

1) Are there any similarities and differences in terms of ideational metaphor embodied in political and business texts and what are the respective frequencies?

2) If such similarities and differences surface, how are they realized textually and ideationally?

And the following hypothesis, accordingly, was formulated:

There are similarities and differences regarding the frequency, process type, role and function of ideational grammatical metaphor in business and political texts.

\subsection{Method}

In the following section, the corpus, i.e., the kinds of materials, and instruments, i.e., the kinds of model or models used to analyze the texts, procedure and design of the study will be talked about.

\subsubsection{Corpus}

Since it was important that the political and business texts used in this study be authentic and formal, an effort was made to select business texts form a book entitled 'Business Result' by Kate Baade \& Christopher Holloway and political texts from a book entitled 'Describing Discourse' by Nicola Woods and Tony Blair's speech to Trimdon Labor club that got out as news from the labor party. Because of time constraints, only 3 business and 3 political texts, 500 words of each genre, were used as the corpus in order to investigate the frequency, process type, role and function of ideational grammatical metaphor and find similarities and differences between two genres in terms of ideational grammatical metaphor. Experts and politician's speeches were chosen for this research because they are very careful in the words they employ to say what they mean, often willfully making the tone of their writing sound more abstract and formal. Furthermore, such texts are believed to contain more ideational grammatical metaphors (Halliday and Matthiessen, 2004).

\subsubsection{Instruments}

In order to bring out potential similarities and differences and find the congruent and metaphorical domains and the process types in these 6 texts (comprising approximately 1000 words of political and business texts), choosing a model is deemed to be of fundamental 
importance. It was in recognition of this line of thinking that the ideas of Martin, Matthiessen \& Painter (1997) and Halliday (1999) provided a reliably comprehensive groundwork to be utilized as the main theoretical foundation of the present research. According to Martin et al (1997), there are 6 process types in English:

1) Material: material clauses construe doings and happenings.

2) Mental: mental clauses construe a person involved in conscious processing, including processes of perception, recognition and affection.

3) Relational: relational clauses construe being and do this in two different modes attribution and identification.

4) Behavioral: behavioral clauses construe human behavior.

5) Verbal: verbal clauses represent processes of saying.

6) Existential: existential clauses resemble relational clauses in that they construe the participant involved in a process of being, but differ from relational ones in that there is only one participant.

According to Halliday (1999), each metaphorical wording must have its equivalent congruent wording. So, in this study, not only process types but also congruent domains of extracted ideational grammatical metaphor instances are discussed, a pursuit which Thompson (2004) refers to as unpacking a grammatical metaphor (arriving at or hypothesizing about a potential wording that mirrors that instance of grammatical metaphor in its congruent domain).

\section{Data Analysis}

\subsection{Introduction}

As introduced before in the introduction of this work, the main objective of the current work is to analyze a corpus comprising 3 business and 3 political texts. These texts were analyzed in order to see how many instances of ideational grammatical metaphor are used in both of the genres and what the respective frequencies are. Further, the data has been looked at so as to also gain an idea of the role and function of ideational grammatical metaphor in these texts.

\subsection{IGM in Political Texts}

Political texts have always been an interesting area for discussion and analysis. In political texts, lexis and grammar are re-arranged in a clever way in order to lure and invite the majority of mass readers into certain states of political action and agenda. The language used by politicians is designed to lead us to a particular view of political reality and to act in a way that is consistent with this view by voting for a particular party, for instance, or edge unawares into a certain territory of thinking, ideology or individual and social decision-making. Ideational grammatical metaphor, in conveying the politician's message in a 
more desirable manner, plays an evidently important role along these lines. It is now established knowledge that metaphors do pervade political discourse (Fadda, 2006). In the discourse of the former British Prime Minister, Tony Blair, metaphors aren't just superficial stylistic adornments; they, in fact, help him construct the country's reality. The following table represents ideational grammatical metaphors in text 1 and 2 of our analysis.

Table 4.1. Ideational grammatical metaphors in political text 1 and 2

\begin{tabular}{|c|c|c|c|}
\hline No & Metaphorical wording & Congruent wording & process \\
\hline 1 & In the face of future challenges & $\begin{array}{l}\text { Up against when facing the challenge } \\
\text { in the future }\end{array}$ & Material \\
\hline 2 & $\begin{array}{l}\text { Provide opportunity and security } \\
\text { for all }\end{array}$ & $\begin{array}{l}\text { Provide what is opportune and (the } \\
\text { feeling of) being secure for all }\end{array}$ & Material \\
\hline 3 & Their class, colour or creed & $\begin{array}{l}\text { How they are classified, what the } \\
\text { colour of their skins are, etc }\end{array}$ & Relational \\
\hline 4 & Economic stability & Economy is stable & Relational \\
\hline 5 & Modern knowledge economy & $\begin{array}{l}\text { Economy which uses a modern } \\
\text { knowledge base }\end{array}$ & Relational \\
\hline 6 & Dynamism & Dynamic attitude or style & Mental \\
\hline 7 & Scientific progress & To progress scientifically & Material \\
\hline 8 & Major investment & Invest in major things & Material \\
\hline 9 & Basis of equity not wealth & $\begin{array}{l}\text { The base is that all people must be } \\
\text { equal; not how wealthy they are }\end{array}$ & Relational \\
\hline 10 & Child poverty & Children are poor & Relational \\
\hline 11 & New security threats & $\begin{array}{l}\text { Somethings threaten how secure you } \\
\text { are and feel }\end{array}$ & material \\
\hline 12 & Obligation of that duty & $\begin{array}{l}\text { How obliged we are to discharge that } \\
\text { duty }\end{array}$ & Material \\
\hline 13 & Fighting terrorism & $\begin{array}{l}\text { Fight against those who are terrorists } \\
\text { and those who terrorize, etc }\end{array}$ & Material \\
\hline 14 & Fighting global poverty & $\begin{array}{l}\text { Try to bring down the number of } \\
\text { poor people around the world }\end{array}$ & Material \\
\hline 15 & Climate change & the climate changing & Material \\
\hline 16 & Its own interest & $\begin{array}{l}\text { The things that are beneficial for } \\
\text { Britain }\end{array}$ & Relational \\
\hline 17 & Genuine opportunity society & $\begin{array}{l}\text { A society that looks constantly for } \\
\text { opportunities (what is opportune) }\end{array}$ & Material \\
\hline 18 & Hard work & Working hard & Material \\
\hline 19 & class or privilege & How they are classified or privileged & Material \\
\hline 20 & In the face of the stress & $\begin{array}{l}\text { When they find themselves stressed } \\
\text { out or in a stressful situation }\end{array}$ & material \\
\hline
\end{tabular}


Instances of ideational grammatical metaphor in text 1 and 2 represent some of the nominalizations that are used frequently by Tony Blair. Out of the 20 extracted ideational grammatical metaphors, 13 embody material process types, 6 of them involve relational process types and only one of them has a mental process when unpacked (turned mirror-wise into its congruent version). Ideational grammatical metaphor serves several important functions.

The following text is extracted from Tony Blair's speech for the purpose of illustration.

It is to modernize our country, so that, in the face of future challenges, intense and profound for us and like nations, we are able to provide opportunity and security for all; not for an elite; not for the privileged few; but for all our people, whatever their colour, class, or creed.

'Future challenges' is an instance of grammatical metaphor. Here, the nominalized grammatical metaphor ((challenge)) enables it to become ((thing)) from the process ((to challenge)) and an epithet (future) to modify it. This allows for certain cognitive and perlocutionary effects on the minds of the hearers when the nominalized group ((future challenges)) is used, including: a vague and uncertain sociopolitical horizon, conceptual and logistical ascendancy of the speaker, his projected honesty and sincerity in seeing the stated horizons through as the perfect human candidate and catalyst to do so and so on. We should note the important and fundamental consideration that the basic point to the evolutionary, semogenic and macro-semantic existence of grammatical metaphor is that the congruent falls short of capturing, configuring and realizing the semantic context aimed at through a grammatical metaphor (Farahani \& Hadidi, 2008); for example, in the second case:

1. ........being able to provide opportunity and security for all

The speaker could not possibly and conceivably capture his intended meaning through the congruent domain; using the metaphorical phrase ((being able to provide opportunity and security for all)) brings in second cognitive and perlocutionary meanings which are socio-politically very important and vital to the covert political agenda of the speaker and his political cohorts, especially as the grammatical metaphor is followed by ((for all)) which creates the impression that the speaker is a puppeteering provider of something otherwise unattainable to the masses.

In (2) below, we come up with an unpacked (congruent version) for the two grammatical metaphors ((fighting terrorism and poverty)) (13 and 14 in the above table); this congruent version will have represented a conceptual phenomenon, in the sense that:

2. There are terrorists and poor people, we fight them both.

\section{Conceptual}

phenomenon

In example (3) the grammar is structured through nouns (class, colour or creed). This example represents a verbal nominalization (classed-class, coloured-colour, creeded- creed). Class, color and creed are head nouns of the possessive their which refers to all of Britain. 
According to Halliday (1999) and Halliday \& Matthiessen (1999), nominalization reduces the number of clauses and more information is able to be compressed into each nominal group.

Compare the following sentences:

3. How they are classed, how they are coloured or creeded. (Congruent wording )

4 ........whatever their class, colour or creed. (Metaphorical wording)

By comparing the two above sentences we can see that several abstract ideas are packed into one single sentence. In the metaphorical wording the tone of writing sounds more expressive and vivid. Here, Tony Blair resorts to grammatical metaphor in order to convey his message in a more efficient way.

When verbs are nominalized, they become concepts rather than actions; as a result, the writer is able to increase the amount and density of information to make further comments or observations about the concept in the sentence (Lakoff, 1991; Wang, n.d). For example, in the following text, Tony Blair states:

5. It is put on the top of the investment in schools and the NHS; the quality and standards of service people expect today and on the basis of equality not wealth.

As argued in Halliday \& Matthiessen (1999), grammatical metaphor serves several important functions like condensing and compacting information. These render possible the expression of concepts and ideologies that are very important in political registers. The meaning mapped out in the above examples concerns all people in Britain. The congruent meaning, we invest in the fields that people want and we fight against capitalism and all of the people must be equal, compared with its metaphorical meaning, isn't as vivid and expressive in adult formal discourse. Here, it is the role of nominalization, the single most powerful resource for creating grammatical metaphor, to do the job of initiating the reader into an ideologically rigged state of affairs, enabling Tony Blair to produce certain effects.

As Halliday \& Matthiessen (2004) and Halliday (1999) make clear, ideational metaphors are found in all types of adult discourse and written language contains and employs more cases of ideational metaphor than spoken discourse. In written language, various lexical meanings are packed into one single nominal group. This is the context in which ideational metaphors occur. The text from Tony Blair's speech at the launch of labour's general elections manifesto deploys several instances of grammatical metaphor. Tony Blair resorts to grammatical metaphor in order to shape the audiences' mindset and ideological ethics along certain desirable lines and, thereupon, to achieve certain political ends.

6. It is to build in Britain the genuine opportunity society, where what matters is hard work, merit, playing by the rules - not class or privilege or background.

For the first instance of ideational grammatical metaphor in sentence 6 above, a quick transitivity analysis is undertaken below. The congruent wording can be drawn as follows:

7. Hard work (metaphorical wording) 
8. Work in a hard way

Hard work $\longrightarrow$

Adj $\quad \mathrm{N}$ (congruent wording)

work in_a_ hard way

verb

The verb (work) in the congruent domain as you see has turned to a noun in the metaphorical domain (work). This is a verbal nominalization and the epithet (hard) pre-modifies the metaphorical word (work). The second case includes two ideational metaphors:

9. not class or privilege

In the first case, Tony Blair makes a point of three key qualities that together define the values of the audience that the campaign is aiming at - they are positive qualities needed for candidates - but in the second example, grammatical metaphors are used to represent elements or negative qualities that are valued by rival parties. The reason that grammatical metaphor arises here is that the congruent domain falls short of condensing and compacting information that is critically/ideologically vital for the politicians' and stakeholders' existence and creating political terms in this political context. Without employing grammatical metaphor, how can Tony Blair be conceivably managing to produce the stylistic, textual, perlocutionary and ideological effects and changes in the reader's mind?

In the same spirit, a simple comparative glance at the metaphorical and congruent domains will reveal how vital the role of grammatical metaphor is in political contexts and the fact that without semogenic recourse to grammatical metaphor (Farahani \& Hadidi, 2008), the desired discourse of politicians would fall short of executing and implementing their power-oriented and discursive applications and agendas.

10 . not class or privilege

11.........how you are socially classified or how you are socially privileged.

Class is metaphorical for the verb classified and privilege for the adjective privileged. As mentioned before, it is the function of ideational grammatical metaphor here to reduce the number of clauses and compressing more information into each nominal group. It is features like these typical of grammatical metaphor that makes the writing more interesting, vivid and expressive.

To fully grasp the sense of this type of nominalization at work in ideational metaphor, the identification and analysis of both the metaphorical and the congruent realizations are essential or, as Halliday \& Matthiessen (2004) put it, a piece of wording that is metaphorical has, as it were, an added dimension of meaning; it means both metaphorically and congruently. For example, consider table 2 that represents ideational grammatical metaphors in text 3. 
Table 4.2. Ideational grammatical metaphors in political text 3

\begin{tabular}{|l|l|l|l|}
\hline No & Metaphorical wording & Congruent wording & Process \\
\hline 21 & Debate globalization & $\begin{array}{l}\text { Debate globalizing trends of the } \\
\text { whole world }\end{array}$ & Material \\
\hline 22 & Indifference to tradition & $\begin{array}{l}\text { People are indifferent to tradition } \\
\text { (what is traditional) }\end{array}$ & Behavioral \\
\hline 23 & Our values & What we value & Material \\
\hline 24 & $\begin{array}{l}\text { Honest understanding of the } \\
\text { reality }\end{array}$ & $\begin{array}{l}\text { To understand the real situation in an } \\
\text { honest way }\end{array}$ & Mental \\
\hline 25 & The temptation & What tempts you & Material \\
\hline 26 & Onslaught of globalization & $\begin{array}{l}\text { Attack of the globalizing trend on the } \\
\text { whole world }\end{array}$ & Material \\
\hline 27 & Workforce & Group of workers & Relational \\
\hline 28 & Regulation & Regulate something & Material \\
\hline 29 & Government subsidy & Government subsidizes something & Material \\
\hline 30 & Rising investment & People are investing more & Material \\
\hline 31 & Treatment & Treat someone & Material \\
\hline 32 & Radical reduction & Reduce radically & Material \\
\hline 33 & Further improvements & Improve more & Material \\
\hline 34 & Cardiac care & Taking care of the heart & Material \\
\hline 35 & Continuing modernization & To continue modernizing something & Material \\
\hline 36 & $\begin{array}{l}\text { The independence and freedom } \\
\text { they want }\end{array}$ & $\begin{array}{l}\text { Being free and independent in the } \\
\text { way that they want }\end{array}$ & Relational \\
\hline 37 & Basis of our skills & What our skills are based on & Relational \\
\hline 38 & Apprenticeship & People who are apprenticed & Material \\
\hline 39 & Justice system & justly which tries to be just or act & Relational \\
\hline 40 & Uniformed presence & Evesent in a uniformed way & Material \\
\hline 41 & Every neighborhood in Britain & Toraid of a criminal trend & Material \\
\hline 42 & Fear of crime & Strict control & Material \\
\hline 43 & antrol something strictly & \\
\hline
\end{tabular}

According to Halliday (1999), transitivity analysis of a clause should be able to show a material process. As the table demonstrates, examples such as $(29,30$, and 31$)$ represent a material process in a transitivity analysis. The nominalization government subsidy in (29) is thus said to realize the meaning of thing (the metaphor: subsidy) as well as that of process (the congruent paradigmatic variant, subsidize).

As you see, Tony Blair's speech is full of instances of ideational metaphor. Without ideational grammatical metaphor, political texts are incomplete and politicians can't produce certain effects and convince a majority of people into certain political purposes and worldviews. The function of ideational grammatical metaphor is vital here in convincing people and capturing the minds of the audience. The success of politicians and their political 
team depends upon grammatical metaphor. In the following text, grammatical metaphor helps Tony Blair construct the country's reality (paradoxically by hiding some realities) by structuring the system of knowledge and beliefs as well as ways of thinking and acting.

Because hard-working families depend on the NHS, we will keep the NHS Free at the point of use with rising investment but thoroughly modernized. To put power in the hands of the patient, to get the treatment they need at the Time they want, with a radical reduction in waiting times and further improvements in cancer and cardiac care.

The above text employs five grammatical metaphors. Look at this example:

12. .......radical reduction in waiting times

13. We radically reduce the times for which patients have to wait.

It may be easily observed that both clauses allow us to describe the same situation. However, the process constituents in (13) have been realized in a congruent fashion, whereas (12) evidences a preference for metaphorical modes of expression. Thus, the metaphorical process reduction is realized by a verb in (13) and is encoded in (12) not as a happening but as a thing. In simple terms, nouns congruently encode things and verbs congruently encode happenings.

Table 4.3. Grammatically congruent and metaphorical wording of a meaning

\begin{tabular}{|c|c|c|}
\hline We reduce radically & radical reduction & wording \\
\hline We reduce radically & & meaning \\
\hline Congruent & metaphorical & \\
\hline
\end{tabular}

When more than one item of a clause may be a metaphorical realization, this is accounted for in terms of syntagmatical plurality. In such cases one occurrence of grammatical metaphor is dependent on another process of metaphor (Simon-Vandenbergen et al, 2003). The feature of syntagmatic plurality makes a distinction between two levels at which ideational metaphors can be analyzed. Simple metaphors can be distinguished from other types of expressions, in which various instances of metaphorical realizations interact with each other. Syntagmatic plurality can be seen in the following ideational grammatical instances extracted from Tony Blair's speeches.

14 ................providing security

15 workforce regulation

16 rising investment

The above examples contain two micro-level metaphors:

14) providing a feeling of being secure 
15) regulating a group of workers and so on.

\subsection{Ideational grammatical metaphor in business texts}

Traditional studies limit metaphor to rhetorical and lexical means, with little consideration expended on grammatical metaphor. But grammatical metaphor is a device used extensively in various written genres of English and, hence, becomes an important concept of systemic-functional grammar. The application of grammatical metaphor comes also to be one of the important stylistic features of business English texts. Since people spend big portions of their lives in business institutions, especially as managers and in a knowledge economy, analyzing and studying them sounds interesting for most people. The language used in business has a persuading force, and there is a driving force behind business messages, i.e. a science of capturing and arresting the human mind to get money from it, in lucid terms. The power of business derives from language though. Words are chosen with care and in keeping with certain formal structures in mind. We can't ignore the important role of grammatical metaphor in arresting, capturing and motivating the human in order so as to put something in their mind and bring them into the world of business. In the second part of this chapter the ideational grammatical metaphors extracted from 3 business texts are represented in tables 4.4 and 4.5 with their congruent wordings and process types.

Generalization is one of the important roles and functions of grammatical metaphor. Grammatical metaphor instances in business texts carry out this function in an excellent way in order to absorb as much as possible of people's attention. In the world of business, expansion is vital and necessary and it can't happen without advertising. The power of language is of evident importance in the world of business and the tool that strengthening the language used is grammatical metaphor. In this genre, persuading and (potentially) deceiving people without grammatical metaphor playing a pivotal textual role would prove very challenging, so business texts resort to grammatical metaphor in order to reach certain desirable persuasive effects and material gains. Look at the following table to see how experts persuade people to join the tour by the excellent and clever use of ideational grammatical metaphor.

Table 4.4. Ideational grammatical metaphors in business text 1 and 2

\begin{tabular}{|l|l|l|l|}
\hline No & Metaphorical wording & Congruent wording & process \\
\hline 1 & Delights & Some of the things that delight you & Mental \\
\hline 2 & Real feel & $\begin{array}{l}\text { What one really feels; how } \\
\text { something really feels }\end{array}$ & Mental \\
\hline 3 & Organization & An organized group of people & Relational \\
\hline 4 & New sales & Things we sell for the first time & Material \\
\hline 5 & Marketing teams & Teams who market items & Material \\
\hline 6 & Career possibilities & $\begin{array}{l}\text { How possible it is to create many } \\
\text { jobs }\end{array}$ & Material \\
\hline 7 & Axtrin's success & Axtrin is successful in an area & Material \\
\hline 8 & $\begin{array}{l}\text { Creativity , performance and } \\
\text { achievement of its staff }\end{array}$ & $\begin{array}{l}\text { How creative the staff are, how they } \\
\text { perform and what they achieve }\end{array}$ & Material \\
\hline
\end{tabular}




\begin{tabular}{|l|l|l|l|}
\hline 9 & Review procedures & Procedures of reviewing & Material \\
\hline 10 & Career review process & The process of reviewing the careers & Material \\
\hline 11 & Management consultancy & Consulting on the ways of managing & Material \\
\hline
\end{tabular}

As the table represents, at the beginning of the sentence, the expert addressing the audience resorts to grammatical metaphor:

17. Join us on this gastronomic tour and let us guide you through some of the delights that the real Madrid has to offer.

Here, the delights is a grammatical metaphor for the adjective "delightful" through a lexical/metaphorical process. The writer uses the excellent word delight to refer to all the places that are delightful. There is a generality here, because delight refers to all pleasurable places the imagination evokes. The hypothetical unpacked version in the congruent domain, some of the things that delight you, falls short of giving generality, so grammatical metaphor arises to fulfill its function in a more vivid and expressive way. Other instances of ideational grammatical metaphor also have a persuasive force and as the table shows all of them are material process types except examples 1,2 , and 3 . It shows the dominant force of material process types in texts 1 and 2 .

As Halliday (2005) and Heyvaert (2005) would agree, nominalization and grammatical metaphor are the main lexicogramatical characteristics of adult written language, used as frequently in business texts as they do in order to achieve materially suasive ends of marketing, selling and wining sustainable customer faith, while also making the writing not too flat, too artificial or too contrived. Nominalization has been used frequently in text 3 to create a more academic and abstract tone.

Table 4.5. Ideational grammatical metaphors in business text 3

\begin{tabular}{|l|l|l|l|}
\hline No & Metaphorical wording & Congruent wording & process \\
\hline 12 & Information system & System that informs people & Material \\
\hline 13 & Their working practices & $\begin{array}{l}\text { How they manage and behave in } \\
\text { their vocations }\end{array}$ & Material \\
\hline
\end{tabular}

Like text 1 and 2, the table shows the dominance of material process type in business texts. This means that some action or event is always happening in the world of business. In order to explain these events and actions in a more interesting way, the use of grammatical metaphor is essential and vital. Look at this example:

18) Nowadays the problem in assessing the possible present risks is that how people progress and how they change isn't linear and we can't predict them. (Congruent wording)

19) The problem in risk assessment is that progression and change in today's world is no longer linear and predictable. (Actual metaphorical wording) 
It may be easily observed that both of the above sentences allow us to describe the same situation. However, the process constituents in (18) have been realized in a congruent fashion, whereas (19) evidences a preference for metaphorical modes of expression. As Ignatieva (2008) mentioned, the congruent wording is almost always longer than the metaphorical one and the tone of writing in (19) is more abstract, formal, lively, compact and, in all likelihood, more effective in discourse.

In business texts that turn out to be more packed and laden with grammatical metaphor, it appears that these grammatical metaphors are driven by the same discoursal motivation; high-frequency technical vocabulary building which gives rise to all these technical business and management textual jargon to be drawn upon and packed into a single text. The following table outlines a few examples of how technical words are used as a grammatical metaphor in business texts.

Table 4.6. Examples of technical words as GM in business texts

\begin{tabular}{|c|c|c|c|}
\hline No & Metaphorical Wording & Congruent Wording & process \\
\hline 28 & Improve efficiency & $\begin{array}{l}\text { Improve how efficiently something } \\
\text { functions }\end{array}$ & Relational \\
\hline 29 & Innovations & Innovative ideas and actions & Mental \\
\hline 30 & Run the risk of & Do some things which are risky & Material \\
\hline 31 & Prevalence of obesity & $\begin{array}{l}\text { Obesity is prevalent; how prevalent } \\
\text { obesity is }\end{array}$ & Relational \\
\hline 32 & Respond to public demand & $\begin{array}{l}\text { Respond to what the public } \\
\text { demands }\end{array}$ & Verbal \\
\hline 33 & Introducing new products & $\begin{array}{l}\text { Introduce the things that are } \\
\text { produced newly }\end{array}$ & Material \\
\hline 34 & Changing environment & The environment is changing & Material \\
\hline 35 & Their production & What they produce & Material \\
\hline 36 & The power of team work & $\begin{array}{l}\text { The power of teams working } \\
\text { together }\end{array}$ & Material \\
\hline 37 & 20 minutes of landing & $\begin{array}{l}20 \text { minutes after the plane has } \\
\text { landed }\end{array}$ & Material \\
\hline 38 & Their ability & They are able to do something & Material \\
\hline
\end{tabular}

\subsection{Discussion}

With reference to the research questions posed in this study, we recapitulate the discussion of the findings in, hopefully, a more lucid way, before concluding remarks.

Ideational grammatical metaphor is an incongruent representation of the experiential meaning in the configuration of the clause. Logical grammatical metaphor refers to ideas that are organized in an incongruent form at the level of discourse. A rather obvious expectation that was construed by the analysis of congruent wording in business and political texts was the higher frequency and dominant textual force of material process types in both of the genres and low frequency of other types. 


\section{$\triangle$ Macrothink}

International Journal of Linguistics

ISSN 1948-5425

2012, Vol. 4, No. 2

The research finds support in the research findings of Halliday (1985) that the ideational grammatical or transitivity analysis should bring out a material process type. Comparing metaphorical and congruent wordings in political and business texts reveals that the metaphorical domain explains the situation in a more interesting, lively, colorful and desirable manner vis-à-vis the semogenetic contingencies of the genre in question. Ideational grammatical metaphors are used frequently in political and business texts, at approximately similar rates. The instances of ideational grammatical metaphor in both genres serve several important functions like condensing, compacting, and creating scientific terms. Ideational grammatical metaphor instances in business texts create expert and professional terms that are available to a quicker conscious mind and invite the reader to make sense of a world structure which is credible, neatly layered and promising in some way. In political texts, however, ideational grammatical metaphor creates the impression that the speaker is a puppeteering provider of something unattainable to the masses.

It seems that, upon analysis, certain grammatical metaphors emerge that are composed of two successive nouns one of which premodifies the other; however, the grammatical metaphor is in fact the condensed metaphorical version of a very nuanced sociopolitical and critical meaning. The speaker resorts to these so-called compound grammatical metaphors in order to convey a desirable meaning connected with his overall political and logistical agenda of power and ideology. What we thus chose to term compound grammatical metaphors are a very interesting metaphorical textual device, the potential existence of which was in fact pointed out by Heyvaert (2003) and Simon-Vanderbergen (2003) in an implicit theoretical manner and this study points along explicit lines to their deployment in political and business texts, while it is also noteworthy that the frequency of such patterns seems to increase when one moves from business texts to political texts.

One could argue that ideological and power manipulation and inculcation of ideological thought patterns in the mind of the masses through the strings pulled by stake-holders, policy makers, decision makers, etc give rise to latent forces that, in turn, embody and fuel political discourse and its textual manifestation.

Last but not least, by way of reiterating a central point, it is important to bear in mind that nominalization is the most common form of ideational grammatical metaphor. Tony Blair in political texts and experts in business texts frequently resort to nominalization in order to convey their meaning in a more abstract, formal and interesting way and produce certain effects.

In the following chapter, which is last, we will present the conclusions drawn from the findings along with some of their possible implications for other language-related disciplines; some suggestions as well will be made for further research.

\section{Conclusion}

The present study managed to show that ideational metaphor has indeed pervaded political and business texts and is used approximately with the same frequency in both genres. Nominalization - a typical process leading to grammatical metaphor - is a striking feature of 
business and political texts and makes the writing more interesting, lively, convincing and colourful. Nominalization has been used in both of the genres, turning the process (verb) to a concept (noun). As a consequence, the tone of the writing sounds more abstract and more formal. In both of the genres, the purpose of using an ideational metaphor is to render the lexis and grammar in such a way as the speaker wants in order to produce a certain effect. In business, the instances of grammatical metaphor aren't coloured and fuelled by relations of power and ideology, but by some latent and mercurial forces in the ever-morphing world of business and marketing; in politics, however, they evidence indicators of uneven power by agents of dominance.

Grammatical metaphor instances in business texts serve several important functions like condensing, compacting and creating technical, expert and professional terms that are available to a quick conscious mind, assuming the job of initiating the reader into certain economic worldviews or rigged states of affairs in a quick, compact and desirable manner.

In politics, ideational grammatical metaphors are used in such a way as to create the impression that the politician is a puppeteering provider of some things otherwise unattainable to the masses, for gradual but powerful and subtle inculcation of sociopolitical ideologies in the minds of the masses, ideologies and conceptualizations desired by the politicians and stake-holders so that these power relations and the unbounded margins of profit targeted therein are left intact and continue to survive unnoticed by awakened ideology and sensitized understanding and perceptions on the part of the citizens. Avoiding these eventualities is of overriding importance to agents of power; since language and discourse are the most important building blocks of such a vital preservation of power and profit, they can't lose sight of operations and processes in text and discourse, be it intentionally or unintentionally

\section{References}

Fadda, S. (2006). The Use of Metaphors in Political Discourse: The Speech of George W. Bush. [Online] Available: http://www.pucsp.br/isfc/proceedings/Artigos\%20pdf/44mtp_fadda_921a931.pdf. (December 10, 2011)

Farahani, A. A., \& Hadidi, Y. (2008). Semogenesis under Scrutiny: Grammatical Metaphor in Science and Modern Prose Fiction. Iranian Journal of Applied Linguistics (IJAL), 11(2), 51- 85.

Halliday, M. A. K. (1985). An Introduction to Functional Grammar. London: Edward Arnold.

Halliday, M. A. K. (1994). An Introduction to Functional Grammar. London: Arnold.

Halliday, M. A. K. (1999). Grammar and the construction of educational knowledge. In The Language of Early Childhood. Volume 4 in the Collected Works of M.A.K. Halliday. London and New York: Equinox. p. 355. 
Halliday, M. A. K., \& Martin, J. R. eds. (1993). Writing science. Literacy and discourse power. London : Flamer press

Halliday, M. A. K., \& Mathiessen, C. M. I. M. (2004). An Introduction to Functional Grammar. London: Arnold.

Halliday, M. A. K., \& Matthiessen, M. I. M . (1999). Construing experience through meaning, a language based approach to cognition. New York: Norfolk

Lakoff, G. (1991). Metaphor in politics. [Online] Available: http://www.compapp.dcu.ie/-tonyv/trinity/lakoff-letter.html (December 10, 2011)

Martin, J. R., Matthiessen, M. I. M., \& Painter, C. (1979). Working with functional grammar. New York: Arnold

Ravelli, J. L. (2003). Renewal of Connection: Integrating Theory and Practice in an Understanding of Grammatical Metaphor. In A. Simon-Vandenbergen, M. Taverniers, and $\mathrm{J}$.

Romero, E., \& Soria, B. The notion of grammatical metaphor in Halliday. [Online] Available: http://www.ugr.es/ bsoria/papers/Grammatical\%20metaphor\%20in\%20Halliday.PDF (December 10, 2011)

Simon-Vandenbergen, A., Taverniers, M., \& Ravelli, J. L. (2003). Grammatical metaphor:views from systemic functional linguistics. Amsterdam/Philadelhia: John Benjamins.

Taverniers, M. (2004). Grammatical metaphors in English. [Online] Available: http://users.Ugent.be/ mtaverni (December 10, 2011)

Thompson, G. (2004). Introducing Functional Grammar. London: Arnold.

Yanning, Y. (2008). Typological interpretation of differences between Chinese and English in grammatical metaphor. Language Sciences. 30/4. 